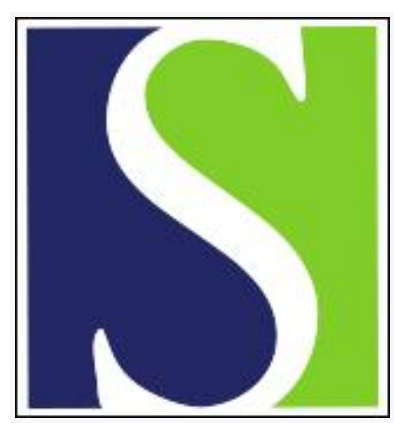

Scand J Work Environ Health 1983;9(2):169-175

https://doi.org/10.5271/sjweh.2438

Issue date: Apr 1983

Preliminary results from a cohort of workers exposed to wollastonite in a Finish limestone quarry.

by Huuskonen MS, Jarvisalo J, Koskinen H, Nickels J, Rasanen J, Asp S

This article in PubMed: www.ncbi.nlm.nih.gov/pubmed/6316484

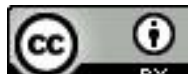




\title{
Preliminary results from a cohort of workers exposed to wollastonite in a Finnish limestone quarry
}

\author{
by Matti S Huuskonen, MD, MSc, ${ }^{1}$ Jorma Järvisalo, MD, ${ }^{1}$ Heikki Koskinen, MD, ${ }^{1}$ \\ Juha Nickels, MD, ${ }^{1}$ Jorma Räsänen, MD, ${ }^{2}$ Sisko Asp, MSc ${ }^{1}$
}

\begin{abstract}
HUUSKONEN MS, JÄRVISALO J, KOSKINEN H, NICKELS J, RÄSÄNEN J, ASP S. Preliminary results from a cohort of workers exposed to wollastonite in a Finnish limestone quarry. Scand $j$ work environ health 9 (1983) 169-175. Wollastonite metasilicate fibers are rather similar in form, length, and diameter, but mineralogically different, to amphibole asbestos fibers. We have studied immunologic findings from 46 men exposed to wollastonite at a limestone quarry for at least 10 years. These workers showed a higher prevalence of positive serum rheumatoid factors than blood donors did. This finding resembles the one detected among asbestos workers. The group of wollastonite workers with radiological signs of pulmonary fibrosis had activities of serum angiotensin-converting enzyme that were similar to those of wollastonite workers without fibrosis. A mortality study of 238 quarry workers with 5,769 person-years was, as expected, nonpositive. It was interesting that one woman with 20 years of exposure to wollastonite and with no other known exposure to fibers revealed a malignant retroperitoneal mesenchymal tumor 30 years after the initial exposure. This kind of very rare tumor is difficult to distinguish from mesothelioma. However, this is only one case, and it is impossible to draw any definite conclusions.
\end{abstract}

Key terms: activity of serum angiotensin-converting enzyme, immune reactions, lung fibrosis, mortality.

Wollastonite is a naturally occurring acicular or fibrous metasilicate used in ceramics and as a substitute for asbestos in some applications. Wollastonite fibers are rather similar to amphibole asbestos fibers in form, length, and diameter, but they are mineralogically different (10). It has been suggested that fiber size is a crucial factor in determining the carcinogenicity of asbestos fibers (16). This suggestion has led to the assumption that other fibers similar to asbestos in size could induce tumors. The first support received for this supposition came from experimental studies; then in 1978 Baris and co-workers (2) found a high incidence

1 Institute of Occupational Health, Helsinki, Finland.

2 Laboratory of Clinical Immunology, Helsinki, Finland.

Reprint requests to: Dr MS Huuskonen, Institute of Occupational Health, Haartmaninkatu 1, SF-00290 Helsinki 29, Finland. of mesothelioma in Turkey among people who were exposed to volcanic nonasbestos silicate minerals called zeolites. The fiber size of zeolites is comparable to that of asbestos fibers. The health hazards of some other naturally occurring nonasbestos mineral fibers (sepiolite, attapulgite and wollastonite) have also been discussed recently $(1,4,15)$.

Caplan (5) was the first to report an association between the findings in chest radiographs and rheumatoid disease in coal miners. Thereafter a high prevalence of rheumatoid and antinuclear antibodies was found in people occupationally exposed to asbestos or quartz $(13,14,18)$. The first extensive study on serum angiotensinconverting enzyme in sarcoidosis, a disease showing pulmonary radiological involvement mimicking pneumoconioses, was published by Lieberman (11). Elevated levels of the serum angiotensin-converting enzyme have also been reported in silicosis 
and asbestosis (7). The part that immunologic activity and the angiotensinconverting enzyme plays in the pathogenesis of pneumoconioses is, however, not clear. Yet their role seems to be of interest, especially in respect to subjects with progressive disease.

We have recently reported the findings of a study of 46 male quarry workers exposed to wollastonite for at least 10 years (average 21.5 years) in a Finnish limestone quarry. Chronic bronchitis occurred in 15 of the men, including three who were nonsmokers. Chest radiographs revealed changes that were similar to those of early asbestosis, including fibrosis in $14(30 \%)$ and bilateral pleural thickening in 13 $(28 \%)$, whereas the respective changes were seldom found among the matched reference groups (9).

In 1981 we started a prospective followup study of wollastonite workers in a limestone quarry. The present report cross-sectionally characterizes the immunologic aspects and the level of activity of the serum angiotensin-converting enzyme of the those quarry workers. In addition the mortality of the workers was studied retrospectively.

\section{Material and methods}

\section{Laboratory findings}

Forty-six men (mean age 48.0 years, range 32 -64) comprised the series for the im- munologic and angiotensin-converting enzyme analyses. The exposure and clinical findings have been described in detail elsewhere (9). Results from a previous random sample of healthy blood donors $(\mathrm{N}=504)$ were used as the reference for the analysis of antibodies (21).

Waaler-Rose, rheumatoid factor-latex, and antinuclear antibodies were measured with standard techniques (19). The rheumatoid factor was also detected by enzyme immunoassay (RF-EIA). The results of the RF-EIA were given in standard deviation units, and the results were considered positive when the score differed from normal by at least 3 SD units (20).

The activities of the angiotensinconverting enzyme were determined according to the method of Chiknas (6).

\section{Mortality}

The data in the present study were taken from personnel records which cover the entire duration of operations at the quarry (in which activity started in 1911) and which include everyone who has ever worked there. Most workers had started work in the quarry in the 1950s (median year 1955). The survey period covered 1923-1980. Only workers who had been on the factory's payroll for at least one year were included. They were followed from the beginning of their first period of employment in the quarry until the end of 1980 or to the date of death, if earlier,

Table 1. Prevalences of antibodies among limestone quarry workers exposed to wollastonite. (RF-EIA = rheumatoid factor detected by enzyme immunoassay, ANA = antinuclear antibodies)

\begin{tabular}{|c|c|c|c|c|c|c|c|}
\hline \multirow{2}{*}{$\begin{array}{l}\text { Immunologic } \\
\text { pattern }\end{array}$} & \multicolumn{2}{|c|}{$\begin{array}{l}\text { All quarry } \\
\text { workers } \\
(N=46)\end{array}$} & \multicolumn{2}{|c|}{$\begin{array}{l}\text { Quarry workers with } \\
\text { lung fibrosis } \\
(\mathrm{N}=14)\end{array}$} & \multicolumn{2}{|c|}{$\begin{array}{l}\text { Quarry workers without } \\
\text { lung fibrosis } \\
(\mathrm{N}=32)\end{array}$} & \multirow{2}{*}{$\begin{array}{c}\text { Blood donors } \\
(\%)\end{array}$} \\
\hline & Number & Percent & Number & Percent & Number & Percent & \\
\hline \multicolumn{8}{|l|}{ Latex } \\
\hline$\geq 1 / 16$ & 16 & $35^{\star * * *}$ & 6 & 43 & 10 & 31 & $4.8^{a}$ \\
\hline$\sum 1 / 32$ & 6 & $13^{* * *}$ & 2 & 14 & 4 & 13 & 0.8 \\
\hline \multicolumn{8}{|l|}{ Waaler-Rose } \\
\hline$\geq 1 / 32$ & 4 & $9^{*}$ & - & 0 & 4 & 13 & $2.0 \mathrm{a}$ \\
\hline$\geq 1 / 128$ & 1 & 2 & - & 0 & 1 & 3 & 0.4 \\
\hline \multicolumn{8}{|l|}{ Positive } \\
\hline $\begin{array}{l}\text { RF-EIA } \\
\text { ANA } \geq 1 / 10\end{array}$ & $\begin{array}{r}74 \\
4\end{array}$ & $\begin{array}{r}30 \\
9\end{array}$ & $\begin{array}{l}3 \\
2\end{array}$ & $\begin{array}{l}21 \\
14\end{array}$ & $\begin{array}{r}11 \\
2\end{array}$ & $\begin{array}{r}34 \\
6\end{array}$ & $\begin{array}{l}19.0^{\mathrm{b}} \\
11 . \mathrm{a}^{\mathrm{a}}\end{array}$ \\
\hline
\end{tabular}

a Determined for 504 blood donors.

b Determined for 89 blood donors.

* $\mathrm{p}<0.05$ and ${ }^{* * *} \mathrm{p}<0.001$ between all quarry workers and blood donors (binomial distribution). 
irrespectively of whether or not they remained on the payroll. The cohort consisted of 238 workers (192 men \& 46 women). For the analysis person-years of follow-up were counted by sex and age for the period 1923-1980.

Past exposure could not be determined in detail (in particular the exposure in the early years of operation). The hygienic measurements performed describe only the level of present exposure, and they probably underestimate the exposure level in earlier years. The workers were divided according to job title into four exposure groups as follows: (i) drilling and blasting; (ii) loading, transport and crushing; (iii) sorting; and (iv) others (leading, fixing, etc). The exposure has been described in more detail elsewhere (9).

It was not possible to obtain reliable information about smoking habits because many of the workers had died long ago.

The causes of death were obtained from the death certificates filed in the Central Statistical Office of Finland. The observed deaths were compared with the expected deaths computed from national age- and sex-specific death rates for 1952-1972. The cause of death was classified according to the eighth revision of the International Distribution of Diseases on Causes of Death (22). The groups of causes analyzed were all causes, all natural causes, diseases of the cardiovascular system, and malignant neoplasms.

\section{Results}

\section{Laboratory findings}

The wollastonite workers showed a higher prevalence of positive rheumatoid factor than the blood donors. No difference was found for rheumatoid factor between quarry workers with and without indications of lung fibrosis in their chest radiographs (table 1). Rheumatoid factor detected by RF-EIA was found to be positive in $30 \%$ of the quarry workers and in $19 \%$ of the blood donors (table 1). The antinuclear antibodies of all classes (immunoglobulins $\mathbf{G}, \mathbf{M} \&$ A) was found in a titer of $\geq 1 / 10$ in $9 \%$ of the wollastonite workers and $11.0 \%$ of the blood donors.

The mean serum activity of the angiotensin-converting enzyme was not significantly different between the workers with and those without pulmonary fibrosis (table 2).

\section{Mortality}

During 1923 to 1980 there were 79 deaths at ages 42 through 93 in the exposed cohort. This number was 17 less than the 96 expected on the basis of the general Finnish mortality rates. There were 67 deaths among the males, compared with 79 expected, and 12 deaths among the females, compared with 17 expected. The data on underlying causes of death, as recorded in the certificates, showed no significant deviations from expectations for malignancies, cardiovascular diseases, all natural causes, or all causes of death (table $3)$.

The observed and expected deaths for the workers with the highest exposure (drilling, transport, crushing) are shown in table 4.

Mortality due to malignomas was also calculated conditional on a 10-year latency period. No difference was found between the observed and expected deaths (table 5). The malignomas found consisted of four bronchial cancers, two ventricular cancers, a cancer of the rectum, and one cancer of the lower lip, as well as one melanoma and one malignant retroperitoneal mesenchymal tumor.

The case of malignant retroperitoneal tumor. A 73-year-old woman (in 1963) had a malignant retroperitoneal tumor. She had done many jobs in the quarry (transport, sorting, etc) between 1933 and 1949. Her known occupational history did not reveal any dust exposure other than

Table 2. The activity of serum angiotensinconverting enzyme (ACE) in wollastonite-exposed workers with and without lung fibrosis.

\begin{tabular}{|c|c|c|c|c|c|}
\hline \multirow[b]{3}{*}{ ACE level $(U / I)$} & \multicolumn{2}{|c|}{$\begin{array}{l}\text { Quarry } \\
\text { workers with } \\
\text { lung fibrosis }\end{array}$} & \multicolumn{3}{|c|}{$\begin{array}{c}\text { Quarry } \\
\text { workers without } \\
\text { lung fibrosis }\end{array}$} \\
\hline & Mean SD & Range & Mean & SD & Range \\
\hline & 22 & $8-38$ & 19 & 6 & $9-36$ \\
\hline
\end{tabular}


Table 3. Observed and expected deaths of the workers exposed to wollastonite in a limestone quarry. Expected deaths (in parentheses) calculated from the general Finnish population in 19521972. (ICD = International Classification of Diseases)

\begin{tabular}{|c|c|c|c|c|c|}
\hline \multirow[b]{2}{*}{$\begin{array}{l}\text { Age group } \\
\text { (years) }\end{array}$} & \multirow[b]{2}{*}{$\begin{array}{l}\text { Person- } \\
\text { years }\end{array}$} & \multicolumn{3}{|c|}{ Cause of death } & \\
\hline & & $\begin{array}{c}\text { Malignomas } \\
(I C D \text { 140-290) }\end{array}$ & $\begin{array}{c}\text { Cardiovascular } \\
\text { diseases } \\
\text { (ICD } 390-458)\end{array}$ & $\begin{array}{l}\text { All natural } \\
\text { causes }\end{array}$ & All causes \\
\hline
\end{tabular}

\section{Male workers}

$\begin{array}{rr}15-24 & 239 \\ 25-34 & 864 \\ 35-44 & 1,175 \\ 45-54 & 1,081 \\ 55-64 & 809 \\ 65-74 & 416 \\ 75-84 & 100 \\ \geq 85 & 12 \\ \text { Total } & 4,696\end{array}$

Female workers

\begin{tabular}{|c|c|c|c|c|c|}
\hline $15-24$ & 23 & $\longrightarrow$ & - & - & - \\
\hline $25-34$ & 91 & 一 & - & 一 & - \\
\hline $35-44$ & 186 & - & - & - & - \\
\hline $45-54$ & 281 & - & - & - & - \\
\hline $55-64$ & 270 & - & - & - & - \\
\hline $65-74$ & 175 & 1 & 5 & 7 & 7 \\
\hline $75-84$ & 47 & 1 & 4 & 5 & 5 \\
\hline$\geq 85$ & - & - & 一 & - & - \\
\hline Total & 1,073 & $2(3)$ & $9(9.1)$ & $12(15.9)$ & $12(16.7)$ \\
\hline
\end{tabular}

Table 4. Observed and expected deaths of limestone quarry workers who had had the highest exposure to wollastonite. Expected deaths (in parentheses) calculated from the general Finnish population in 1952-1977. (ICD = International Classification of Diseases)

\begin{tabular}{|c|c|c|c|c|c|}
\hline \multirow[b]{2}{*}{$\begin{array}{l}\text { Age group } \\
\text { (years) }\end{array}$} & \multirow[b]{2}{*}{$\begin{array}{l}\text { Person- } \\
\text { years }\end{array}$} & \multicolumn{3}{|c|}{ Cause of death } & \\
\hline & & $\begin{array}{l}\text { Malignomas } \\
\text { (ICD } 140-290)\end{array}$ & $\begin{array}{c}\text { Cardiovascular } \\
\text { diseases } \\
\text { (ICD } 390-458)\end{array}$ & $\begin{array}{l}\text { All natural } \\
\text { causes }\end{array}$ & All causes \\
\hline
\end{tabular}

\section{Male workers}

$15-24$
$25-34$
$35-44$
$45-54$
$55-64$
$65-74$
$75-84$
$\geq 85$

Total

Female workers

$15-24$
$25-34$
$35-44$
$45-54$
$55-64$
$65-74$
$75-84$
$\geq 85$

Total

154
680
940
769
505
247
55
4
3,354

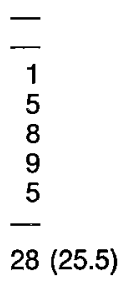

\begin{tabular}{lllll}
- & - & - & - & - \\
26 & - & - & - & - \\
74 & - & - & - & - \\
82 & - & 2 & - & 3 \\
61 & - & 2 & - & - \\
16 & $1(0.1)$ & $4(3.0)$ & $5(5.2)$ & $5(5.4)$ \\
\hline 259 & & & - & 2
\end{tabular}

$\begin{array}{rr}- & - \\ 2 & 3 \\ 7 & 11 \\ 11 & 14 \\ 13 & 13 \\ 6 & 6 \\ 1 & 1 \\ 40 & 48\end{array}$

$40(46.3)$

$48(51.3)$ 
Table 5. Observed and expected malignomas conditional on a 10-year period of latency. Expected deaths (in parentheses) calculated from the general Finnish population in 1952-1972. (ICD = International Classification of Diseases)

\begin{tabular}{|c|c|c|c|c|}
\hline \multirow{2}{*}{$\begin{array}{l}\text { Age group } \\
\text { (years) }\end{array}$} & \multirow{2}{*}{$\begin{array}{l}\text { Person- } \\
\text { years }\end{array}$} & \multicolumn{3}{|c|}{ Malignant neoplasms } \\
\hline & & Bronchial cancers & All cancers & ICD code \\
\hline \multicolumn{5}{|c|}{ Male workers } \\
\hline $\begin{array}{r}15-24 \\
25-34 \\
35-44 \\
45-54 \\
55-64 \\
65-74 \\
75-84 \\
\geq 85\end{array}$ & $\begin{array}{r}4 \\
236 \\
668 \\
766 \\
679 \\
366 \\
100 \\
12\end{array}$ & $\begin{array}{l}- \\
- \\
1 \\
1 \\
2 \\
-\end{array}$ & $\begin{array}{l}- \\
1 \\
2 \\
1 \\
3 \\
1 \\
-\end{array}$ & $\begin{array}{l}- \\
\overline{174} \\
154,162 \\
162 \\
162,162,151 \\
173 \\
-\end{array}$ \\
\hline Total & 2,831 & $4(5.0)$ & $8(13.2)$ & - \\
\hline \multicolumn{5}{|c|}{ Female workers } \\
\hline $\begin{array}{c}15-24 \\
25-34 \\
35-44 \\
45-54 \\
55-64 \\
65-74 \\
75-84 \\
\geq 85 \\
\text { Total }\end{array}$ & $\begin{array}{r}- \\
14 \\
53 \\
134 \\
207 \\
175 \\
47 \\
630\end{array}$ & $\begin{array}{l}= \\
= \\
= \\
= \\
= \\
-(0.2)\end{array}$ & $\begin{array}{l}= \\
= \\
\overline{-} \\
\frac{1}{1} \\
\frac{2}{2}(2.6)\end{array}$ & $\begin{array}{l}- \\
E \\
\overline{-} \\
158 \\
151 \\
-\end{array}$ \\
\hline
\end{tabular}



Fig 1. Light micrograph of a retroperitoneal tumor showing malignant mesenchymal cells infiltrating the adipose tissue $(575 \times)$. 
this quarry work. She was a nonsmoker. Her malignoma was first observed in 1963 , and she died three to four months after the first symptoms of the tumor appeared. Light microscopy revealed a malignant neoplasm which infiltrated the retroperitoneal fat tissue (fig 1). The cells consisted of enlarged, hyperchromatic nuclei with one to several prominent nucleoli. The cytoplasm did not contain fat, mucin, or keratin. Many mitotic figures were seen. Malignant mesenchymal tumor was diagnosed. A diagnosis of metastatic carcinoma was considered but the lack of mucin, keratin, and organized structures spoke against it. Electron microscopy of deparaffinized material showed intracytoplasmic microfilaments and a moderate amount of rough endoplasmic reticulum but no microvilli, desmosomes, or lipid vacuoles, all of which are consistent with a poorly differentiated mesenchymal tumor. However, a mesothelioma cannot be excluded because these structures have also been described in malignant diffuse mesothelioma (17). The slides were later sent to the British Mesothelioma Panel, which concluded that the neoplasm was a poorly differentiated epithelial tumor, but mesothelioma could not be ruled out.

\section{Discussion}

Exposure to naturally occurring mineral fibers other than asbestos has been connected with the same type of health hazards as asbestos exposure $(1,2,4,12)$. Exposure to wollastonite can also cause changes in the pleura and the parenchyma of the lungs (9). However no information is available concerning immunologic findings, the serum activity of the angiotensin-converting enzyme, or the mortality of the workers exposed to wollastonite.

The prevalence of positive rheumatoid factors is increased in asbestos workers with or without asbestosis $(8,18)$. Our results suggest a similar finding for workers exposed to wollastonite in a limestone quarry. However whether the development of the rheumatoid factor in quarry workers is merely a secondary phenomenon or whether it is a sign of immunologic activity, based either on genetic factors or on the process of the disease itself, remains to be solved.

The serum level of the angiotensinconverting enzyme is associated with disease activity in sarcoidosis (11). A correlation of disease activity with the activity level of this enzyme in silicosis or asbestosis has not yet been published, even if elevated serum levels of the angiotensinconverting enzyme have been observed (7). Our results suggest no correlation of serum angiotensin-converting enzyme in wollastonite workers with slight pulmonary fibrosis. Similarly silicosis patients with slight fibrosis do not have elevated serum angiotensin-converting enzyme levels in comparison with silica-exposed referents either, but silicosis patients with advanced fibrosis do (personal communation from $\mathrm{H}$ Koskinen).

Chrysotile asbestos fibers, which are smaller in diameter than amphibole asbestos fibers, are mainly found in human parietal pleura (3). Respirable wollastonite fibers, characteristically $0.2-0.3 \mu \mathrm{m}$ in diameter and several diameters in length, are physically comparable to amphibole asbestos fibers, which have been found to migrate from the pleural cavity to lung parenchyma in animal experiments (3). In the present study a woman with no exposure to fibers other than wollastonite showed a malignant retroperitoneal mesenchymal tumor. This is only one case, of course, and it is thus impossible to draw definite conclusions, but the very rare tumor belongs to the same group as mesotheliomas, and asbestos and some other naturally occurring silicate fibers (physically resembling asbestos) have been found to be involved in the pathogenesis of mesothelioma.

\section{Acknowledgments}

We are especially indebted to the Partek Co for their valuable assistance throughout the entire work. We also wish to extend our appreciation to Dr JSP Jones and his colleagues on the British Mesothelioma Panel for their assistance in explaining the microscopic findings, and to Ms I Saari for typing the manuscript. 


\section{References}

1. Baris YI, Sahin AA, Erkan ML. Clinical and radiological study in sepiolite workers. Arch environ health 35 (1980) 343-346.

2. Baris $\mathrm{YI}$, Sahin AA, Ozesmi M, Kerse I, Ozen E, Kolacan B, Altinörs M, Götkepeli A. An outbreak of pleural mesothelioma and chronic fibrosing pleurisity in the village af Karain Urgüp in Anatolia. Thorax 33 (1978) $181-192$.

3. Bignon J, Monchaux $G$, Sebastian $P$, Hirsch A, Lafuma J. Human and experimental data on translocation of asbestos fibers through the respiratory system. Ann ny acad sci 330 (1979) (745-750.

4. Bignon $J$, Sebastion $P$, Gaudichet $A$, Jaurand MC. Biological effects of attapulgite. In: Wagner JC, Davis W, ed. Biological effects of mineral fibers. Volume 1. International Agency for Research on Cancer, Lyon 1980, pp 163-181.

5. Caplan A. Certain unusual radiographic appearances in the chest of coal miners suffering from rheumatoid arthritis. Thorax 8 (1953) $29-37$

6. Chiknas SG. A liquid chromatography assisted assay for angiotensin-converting enzyme (peptidyl dipeptidase) in serum. Clin chem 7 (1979) 1259-1262.

7. Grönhagen-Riska C, Kurppa K, Fyhrquist $F$, Selroos O. Angiotensin-converting enzyme and lysozyme in silicosis and asbestosis. Scand j resp dis 59 (1978) 228231.

8. Huuskonen MS, Räsänen JA, Härkönen $H$, Asp $S$. Asbestos exposure as a cause of immunological stimulation. Scand $j$ resp dis 59 (1978) 326-332.

9. Huuskonen MS, Tossavainen A, Koskinen $\mathrm{H}$, Zitting A, Korhonen $\mathrm{O}$, Nickels $\mathrm{J}$, Korhonen $\mathrm{K}$, Vaaranen $\mathrm{V}$. Wollastonite exposure and lung fibrosis. Environ res (in press).

10. Korhonen K, Tossavainen A. Wollastoniitti - kuituinen teollisuusmineraali. [Wollastonite - A fibrous industrial mineral]. Vuoriteollisuus 39 (1981) 38-45.

11. Lieberman J. Elevation of serum angiotensin-converting enzyme (ACE) level in sarcoidosis. Am j med 59 (1975) 365-372.

12. Lilis R. Fibrous zeolites and endemic mesothelioma in Cappadocia, Turkey. J occup med 8 (1981) 548-550.

13. Pernis E. Silicosis. In: Miescher PA, Muller HJ, ed. Textbook of immunopathology. Volume I. Grune and Straton, New York, NY 1969, p 293.

14. Pernis E, Vigliani EC, Selikoff IJ. Rheumatoid factor in serum of individuals exposed to asbestos. Ann ny acad sci 132 (1965) 112--120.

15. Shasby DM, Petersen M, Hodous $\mathrm{T}$, Boehlecke B, Merchant J. Respiratory morbidity of workers exposed to wollastonite through mining and milling. In: Lemen R, Dement JM, ed. Dust and disease. Pathotox Publishers Inc, Park Forest South, IL 1979, pp 251-256.

16. Stanton MF, Wrench C. Mechanisms of mesothelioma induction with asbestos and fibrous glass. $J$ natl cancer inst 48 (1972) $797-821$.

17. Suzuki Y, Churg J, Kannerstein M. Ultrastructure of human malignant diffuse mesothelioma. Am j pathol 85 (1976) 241262.

18. Turner-Warwick M, Parkes WR. Circulating rheumatoid and antinuclear factors in asbestos workers. Br med j 3 (1970) $492-495$.

19. Wager $O$. Immunological diagnosis of rheumatoid arthritis and systemic lupus erythematous. Ann clin res 7 (1975) 168182.

20. Wager $O$, Lindström $P$, Räsänen JA, Kekomäki R, Ziola $B$, Salmi A, Isomäki $H$, Skrifvars B, Penttinen K. Evaluation of six tests for circulating IgG complexes with special reference to IgM rheumatoid factors: Analysis of systemic Iupus erythematosus and rheumatoid arthritis series. Clin exp immunol 46 (1981) 149160.

21. Wager O, Räsänen JA. Kliininen immunologinen laboratorio: Ohjekirja. Helsingin Paino Oy, Helsinki 1982. 82 p.

22. World Health Organization. World health statistics annual 1967: Vital statistics and causes of death. Geneva 1970. 